AL-ARD

JURNAL

AL-ARD: JURNAL TEKNIK LINGKUNGAN

Vol.3 No.1 - September 2017(06-13)

\title{
KAJIAN POTENSI PEMANFAATAN SAMPAH PLASTIK MENJADI BAHAN BAKAR CAIR
}

\author{
Gina Lova Sari \\ UniversitasSingaperbangsaKarawang, Karawang, Indonesia \\ Email: ginalovasari@gmail.com
}

\begin{abstract}
The abundance of plastic waste is caused by inadequate management. The element of plastic waste consists of crude oil and natural gas that can be reuse as fuel. The conversion technique which can be applied is thermal cracking as known as pyrolysis that combined with a catalyst. The addition of a catalyst can accelerate the process of crude oil formation so that the volume increases and makes the quality better. The pyrolysis can convert waste into oilup to $81 \%$ that are consist of paraffin, isopropyl, olefin, naphthal and aromatics so feasible to use as fuel.
\end{abstract}

Keywords: catalyst, crude oil, fuel, plastic waste, pyrolysis.

\begin{abstract}
Abstrak
Volume sampahplastik yang melimpahdisebabkanolehtidakmaksimalnyapengelolaan yang dilakukan. Jikadiihatdariunsurpenyusunnya, sampah plastik terdiridari minyak bumi dan gas alam yang apabiladikonversidapat dimanfaatkan kembalimenjadi bahan bakar. Teknik konversi yang dapat diaplikasikan adalah thermal cracking yang lazimnya dikenalsebagai pirolisis dandikombinasikan dengan penambahan katalis. Penambahan katalis mampu mempercepat proses pembentukan minyak sehingga jumlah yang dihasilkan lebih banyak dan kualitasnya meningkat. Pirolisissampahplastikdapat menghasilkan minyak hingga $81 \%$ yang termasuk dalam kategori parafin, isoparafin, olefin, naphthene dan aromatik sehingga layak dimanfaatkan sebagai bahan bakar.
\end{abstract}

Kata kunci: Bahan bakar, katalis, minyakbumi, pirolisis, sampah plastik.

\section{PENDAHULUAN}

Permasalahan global yang hingga kini belum terselesaikan adalah volume sampah yang jumlahnya terus meningkat seiring dengan bertambahnya jumlah penduduk (Guan dkk., 2009; Bajus dan Hajekova, 2010; Ermawati, 2011; Sarker dkk., 2012; Straka dan Bicakova , 2014; Syamsiro dkk., 2014). BPS memperkirakan jumlah penduduk Indonesia pada tahun 2015 mencapai 260.000 jiwa, maka dapat diperkirakan bahwa jumlah sampah yang ditimbulkan adalah 130 ton/hari. Jumlah yang lebih besar ditemukan pada negara Jepang yang volume sampah plastiknya mencapai 10 juta ton per tahun (Nishino dkk., 2003). Hal ini menyebabkan potensi terjadinya kontaminasi dan pencemaran lingkungan semakin besar. Untuk menangani masalah tersebut, telah dilakukan berbagai upaya untuk mengurangi jumlah timbulan sampah yang meliputi 3R (reduce, reuse, recycle).

Reduce umumnya dilakukan pada sumber sampah dengan mengurangi konsumsi sehingga sampah yang dihasilkan juga berkurang. Selanjutnya sampah dipisahkan sesuai dengan jenisnya yaitu organik dan anorganik untuk upaya penggunaan kembali (reuse) dan daur ulang (recycle). Sampah organik yang bersifat bioderadable dimanfaatkan sebagai bahan baku pembuatan kompos (Guan dkk., 2009; Straka dan 
khususnya plastik yang bersifat nondegradable (Santoso, 2010; Rizka dan Juliastuti, 2013; Obeid dkk., 2014) umumnya dimanfaatkan sebagai bahan baku pembuatan kerajinan. Selain itu, plastik dapat dikumpulkan dan dijual untuk diproses lebih lanjut oleh perusahaan daur ulang (Ermawati, 2011).

Pemanfaatan sampah plastik dinilai kurang menarik sehingga daya jualnya terbilang rendah terutama barang kerajinan. Hal ini mengakibatkan upaya reduksi plastik seringkali tidak efektif walaupun jumlahnya cukup banyak. Komposisi sampah plastik menurut Pahlevi dalam Surono (2013); Straka dan Bicakova (2014); dan Syamsiro dkk. (2014) mencapai $10-15 \%$ atau 13,0-19,5 ton/hari dari jumlah keseluruhan sampah perkotaan. Namun sangat disayangkan sampah plastik dengan jumlahnya yang besar hanya dibuang ke TPA atau dibakar tanpa dimanfaatkan semaksimal mungkin (Ermawati, 2011; Marnoto dan Sulistyowati, 2012; Obeid dkk., 2014; Straka dan Bicakova, 2014).

Jika plastik dilihat dari proses pembuatannya yang menggunakan hasil distilasi minyak bumi jenis nafta dan gas alam (Bajus dan Hejakova, 2010), maka sampah plastik berpotensi untuk diolah menjadi bahan bakar alternatif (Ermawati, 2011; Sarker dkk., 2012; Harshal dan Syailendra, 2013; Surono, 2013). Pemanfaatan ini mendapatkan perhatian serius dari beberapa negara seperti Jepang dan Cina (Nishiro dkk., 2003; Surono, 2013; Straka dan Bicakova, 2014). Pemanfaatan tersebut selain dapat mengurangi volume sampah yang ditimbulkan, juga dapat membantu mengatasi masalah global lain yaitu semakin menipisnya ketersediaan minyak bumi sementara kebutuhannya terus meningkat (Ermawati, 2011; Liu dkk., 2012; Tamilkolundu dan Murgunsen, 2012; Harshal dan Syailendra, 2013; Syamsiro dkk., 2014).

Beberapa penelitian menunjukkan bahwa teknik pemanasan dapat digunakan untuk mengolah sampah plastik menjadi bahan bakar (Guan dkk., 2009; Ermawati, 2011). Melalui proses pemanasan, hidrokarbon yang merupakan komponen penyusun plastik akan menguap menjadi gas. Selanjutnya gas tersebut dikondensasi dan terbentuklah zat cair yang kualitasnya hampir sama dengan bahan bakar (Bajus dan Hajekova, 2010). Berdasarkan uraian proses tersebut maka pemahaman mengenai proses konversi tersebut sangat penting. Makalah ini bertujuan untuk menyajikan tinjauan tentang teknologi dan proses konversi sampah plastik menjadi minyak sehingga dapat dimanfaatkan dan bernilai ekonomi berdasarkan beberapa peneltian dan aplikasi yang dilakukan.

\section{KARAKTERISTIK DAN POTENSI SAMPAH PLASTIK}

Plastik merupakan material yang terbentuk dari proses polimerisasi karbon dan hidrogen yaitu proses penggabungan beberapa molekul sederhana menjadi molekul besar. Menurut Santoso (2010); Ermawati (2011); Surono (2013) dan Obeid dkk. (2014), plastik merupakan material yang kuat dan tidak mudah pecah, ringan, anti karat, mudah diwarnai dan dibentuk, serta isolator panas dan listrik yang baik. Sifatnya tersebut menyebabkan penggunaan plastik dalam berbagai aktivitas di kehidupan sehari-hari cukup besar sehingga menghasilkan sampah dengan jumlah yang besar pula (Sarker dkk., 2012; Rizka dan Juliastuti, 2013).

Plastik terbagi menjadi 2 jenis yaitu thermoplastik dan thermosets. Thermoplastik merupakan plastik yang jika dipanaskan hingga suhu tertentu akan mencair dan dapat dibentuk kembali sesuai kebutuhan. Thermoplastik umumnya digunakan sebagai bahan pembuat botol kemasan dan dapat didaur ulang. Sedangkan thermosets adalah plastik yang apabila dipanaskan tidak dapat mencair kembali. Plastik jenis ini digunakan sebagai bahan baku kantong plastik (Bajus dan Hajekova, 2010; Surono, 2013). Thermoplastik terbagi menjadi beberapa jenis yang selengkapnya dapat dilihat pada Tabel 1.

Salah satu bahan baku pembuatan plastik adalah hasil distilasi minyak bumi jenis nafta dengan titik didih maksimal $36-270^{\circ} \mathrm{C}$ (Radionsono dkk., 2006). Dalam pemanfaatannya nafta digunakan sebagai pelarut, bahan kimia, plastik, dan bahan bakar kendaraan jenis bensin (Surono, 2013). Oleh karena itu, sampah plastik berpotensi untuk diolah kembali menjadi bahan bakar kembali (Rodiansono, Trisurnayanti, dan Triyono 2006).

\section{KONVERSI SAMPAH PLASTIK MENJADI BAHAN BAKAR}

Pemanfaatan sampah plastik dilakukan dengan merubah bentuknya yang padat menjadi cair dan gas dengan prinsip pemanasan. Sampah plastik tidak diolah dengan cara dibakar karena prosesnya yang 
tidak sempurna akan menghasilkan senyawa bersifat karsinogen seperti polychloro dibenzodioxins dan polychloro dibenzo-furans. Untuk menghilangkan sifat karsinogennya, maka sampah plastik harus dibakar dengan suhu yang tinggi hingga $1000^{\circ} \mathrm{C}$ sehingga dibutuhkan biaya yang besar (Ermawati, 2011). Pembakaran sampah plastik tidak bernilai ekonomi karena hanya menghasilkan asap dan abu (Gambar 1) yang tidak dapat dimanfaatkan.

Tabel 1. Jenis dan Karakteristik Berbagai Plastik

\begin{tabular}{|c|c|c|c|}
\hline Jenis & Simbol & $\begin{array}{c}\text { Titik Leleh } \\
\left({ }^{\circ} \mathrm{C}\right)\end{array}$ & Monomer Penyusun \\
\hline $\begin{array}{l}\text { PET } \\
\text { (polyethylene } \\
\text { terephthalate) }\end{array}$ & & 250 & $\begin{array}{c}\text { Glikol (EG) dan } \\
\text { terephtalic acid (TPA) } \\
\text { atau dimetyl ester atau } \\
\text { asam terepthalat } \\
\text { (DMT) }\end{array}$ \\
\hline
\end{tabular}

\begin{tabular}{|c|c|c|c|}
\hline $\begin{array}{l}\text { HDPE } \\
\text { (high density } \\
\text { polyethylene) }\end{array}$ & 2) & $200-280$ & - \\
\hline $\begin{array}{l}\text { PVC (polyvinyl } \\
\text { chloride) }\end{array}$ & $\widehat{3}$ & $160-180$ & Monomer vinil klorida \\
\hline $\begin{array}{l}\mathrm{LDPE} \\
\text { (low density } \\
\text { polyethylene) }\end{array}$ & 4 & $160-240$ & - \\
\hline $\begin{array}{l}\text { PP } \\
\text { (polypropylene } \\
\text { atau } \\
\text { polypropene) }\end{array}$ & 5 & $200-300$ & $\begin{array}{l}\text { Polimerisasi gas } \\
\text { propilena }\end{array}$ \\
\hline PS (polystyrene) & $\widehat{65}$ & $180-260$ & $\begin{array}{c}\text { Monomer-monomer } \\
\text { stirena hasil } \\
\text { dehidrogenase etil } \\
\text { benzena }\end{array}$ \\
\hline
\end{tabular}

PC

(polycarbonat)

ABS

(acrylonitrile butadiene

styrene)

PA (polyamide) तु) 260-290

PA (polyacetal) 77) 185-225 $\begin{gathered}\text { Homopolimer (asetal } \\ \text { homopolimer) dan }\end{gathered}$ kopolimer.

(Sumber: Mujiarto, 2005; Bajus dan Hejakova, 2010; Santoso, 2010; Ermawati, 2011; Surono, 2013)

Upaya untuk memanfaatkan sampah plastik menjadi bahan bakar dapat dilakukan dengan metode perekahan (cracking). Cracking adalah proses pemecahan polimer yang molekulnya besar menjadi senyawa dengan berat molekul lebih rendah. Ada beberapa jenis teknologi cracking yaitu hydro cracking, thermal cracking, dan catalytic cracking. Hydro cracking adalah proses perekahan polimer dengan bantuan hidrogen (tekanan 3-10 Mpa dan suhu 423- $673^{\circ} \mathrm{K}$ ) yang dilengkapi dengan pengaduk. Thermal cracking adalah proses pemanasan polimer tanpa menggunakan $\mathrm{O}_{2}$, proses ini lazimnya disebut pirolisis. Teknologi pemanasan lain yang hampir sama dengan pirolisis adalah gasifikasi tetapi prosesnya membutuhkan sedikit $\mathrm{O}_{2}$ (lihat Gambar 1). Sedangkan catalytic cracking adalah pemanasan polimer dengan bantuan katalis sehingga prosesnya lebih cepat dengan suhu yang lebih rendah. Dalam prosesnya, pirolisis dan gasifikasi juga dapat disebut catalytic cracking karena dalam aplikasinya ditambahkan katalis sehingga menghasilkan minyak dan gas dengan jumlah dan kualitas yang lebih baik (Harshal dan Syailendra, 2013: Surono, 2013; Syamsiro dkk., 2014).

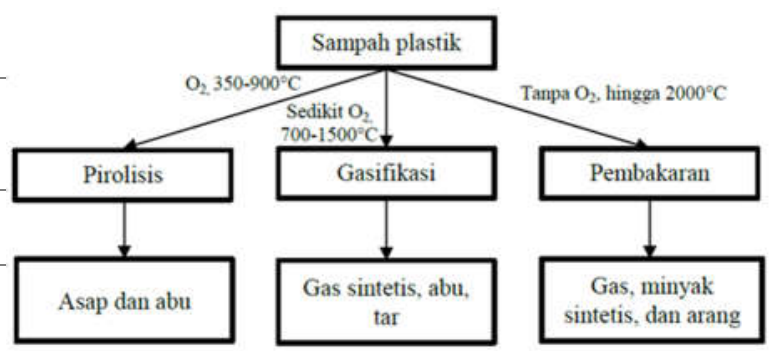

Gambar 1. Perbedaan Pembakaran, Gasifikasi, dan Pirolisis

(Sumber: Bajus dan Hajekova, 2010; Anonim, 2011: Sarker dkk., 2012; Obeid dkk., 2014; Syamsiro dkk., 2014)

Berdasarkan beberapa penelitian yang telah dilakukan, teknologi yang lebih efektif digunakan dalam proses konversi sampah plastik menjadi bahan bakar adalah pirolisis dan gasifikasi yang dikombinasikan dengan catalytic cracking (Bajus dan Hajekova, 2010; Marnoto dan Sulistyowati, 2012; Sarker dkk., 2012; Obeid dkk., 2014; Syamsiro dkk., 2014). Perbedaan antara pirolisis dan gasifikasi dapat dilihat pada Gambar 1. Berdasarkan gambar tersebut, diketahui bahwa perbedaannya adalah suhu, kebutuhan $\mathrm{O}_{2}$, dan produk yang dihasilkan.

Apabila dilihat dari suhu yang digunakan maka pirolisis menjadi teknik pemanasan yang lebih efisien dibandingkan gasifikasi karena energi yang diperlukan lebih sedikit. Jika dilihat dari jumlah $\mathrm{O}_{2}$ yang dibutuhkan, maka diketahui bahwa pirolisis tidak membutuhkan suplai udara ke dalam reaktornya sehingga laju pemanasan akan lebih cepat. Sedangkan gasifikasi masih membutuhkan sedikit udara dalam prosesnya sehingga dibutuhkan suplai udara ke dalam reaktor yang terus dikontrol agar tidak berlebihan. Kebutuhan udara ini umumnya ditunjukkan dengan air fuel ratio 
(AFR). Jika AFR adalah 0, maka proses disebut pirolisis. Jika AFR adalah $<1,5$ maka proses disebut gasifikasi. Sedangkan jika AFR $>1,5$ maka proses disebut pembakaran. Semakin banyak udara yang dibutuhkan maka semakin banyak pula emisi gas yang dihasilkan sehingga berpotensi untuk mencemari udara.

Jika dilihat dari produk yang dihasilkan, pirolisis dan gasifikasi jelas menghasilkan produk yang berbeda. Pirolisis menghasilkan gas, minyak sintetis dan arang sedangkan gasifikasi menghasilkan gas sintetis, abu, dan tar. Hal ini menunjukkan bahwa pemilihan teknik pemanasan yang digunakan sebaiknya disesuaikan dengan produk yang diharapkan. Jika produk yang diharapkan adalah minyak maka pirolisis adalah teknik yang tepat (Bajus dan Hajekova, 2010; Obeid dkk., 2014). Apabila produk yang diinginkan adalah gas dalam jumlah besar yang digunakan sebagai energi pembangkit listrik maka gasifikasi yang lebih tepat.

\section{PIROLISIS DAN CATALYTIC CRACKING}

Pirolisis adalah proses pemecahan struktur polimer kompleks menjadi lebih sederhana pada suhu $350-900^{\circ} \mathrm{C}$ tanpa menggunakan $\mathrm{O}_{2}$ (Sumarni dan Purwanti, 2008; Harshal dan Syailendra, 2013; Obeid dkk., 2014; Syamsiro dkk., 2014). Proses konversi sampah plastik dimulai dari proses drying sehingga didapatkan plastik yang bersih dan kering. Kondisi plastik tersebut akan mempengaruhi kualitas produk yang dihasilkan. Kemudian proses dilanjutkan dengan pemanasan reaktor dengan suhu $350-900^{\circ} \mathrm{C}$. Panas yang terbentuk dari suhu tersebut menyebabkan polimerpolimer plastik di dalam reaktor melunak. Bersamaan dengan itu, polimer yang merupakan molekul besar, strukturnya terdekomposisi menjadi senyawa dengan berat molekul yang lebih rendah dan stabil (Harshal dan Syailendra, 2013; Syamsiro dkk., 2014). Gas yang terbentuk mengandung berbagai unsur dan senyawa yang kemudian dipisahkan melalui proses kondensasi sehingga dihasilkan minyak dan gas. Rodiansono dkk. (2006) melaporkan bahwa pirolisis mampu menghasilkan minyak dan gas yang jumlahnya masing-masing sebanyak $70-80 \%$ dan $5-10 \%$. Ilustrasi sederhana proses tersebut disajikan pada Gambar 2.

Sumarni dan Purwanti (2008) menjelaskan bahwa mekanisme dekomposisi polimer melalui 3 tahap yaitu awal, perambatan, dan perhentian. Pada tahap awal yang ditandai dengan meningkatnya suhu akan terjadi pemutusan rantai polimer dengan ikatan yang lemah. Ikatan yang terputus dan bersifat tidak stabil sehingga mudah bereaksi dengan molekul lain dan membentuk senyawa baru pada tahap perambatan. Selanjutnya, senyawa yang terbentuk akan terpecah membentuk senyawa yang lebih sederhana dan stabil. Senyawa-senyawa tersebut kemudian tervolatilisasi menmbentuk gas (Harshal dan Syailendra, 2013; Syamsiro dkk., 2014). Sebagai contoh pirolisis plastik LDPE, pada tahap awal hingga prambatan akan membentuk senyawa etilena dengan rumus R$\mathrm{CH}_{2}-\mathrm{CH}_{2} \rightarrow \mathrm{R}+\mathrm{CH}_{2}=\mathrm{CH}_{2}$. Pada suhu tertentu, etilena merupakan senyawa yang stabil, tetapi $\mathrm{R}$ yang terbentuk masih bersifat tidak stabil. Oleh karena itu, pada tahap penghentian etilena akan terpecah lagi dan membentuk senyawa yang stabil. Adapun rumus kimia senyawa tersebut adalah $\mathrm{C}_{3} \mathrm{H}_{7}+\mathrm{CH}_{3} \rightarrow \mathrm{C}_{4} \mathrm{H}_{10}$ (Sumarni dan Purwanti, 2008).

Penelitian yang dilakukan oleh Bajus dan Hajekova (2010) menjelaskan bahwa gas yang dihasilkan dari proses dekomposisi sampah plastik jenis LDPE, HDPE, PS, PP, PVC, dan PET pada suhu $350-500^{\circ} \mathrm{C}$ mengandung $\mathrm{CO}, \mathrm{CO}_{2}$, dan berbagai senyawa aromatik. Senyawa aromatik tersebut meliputi benzena, toluena, xylena, etil benzene, dan stirena. Marnoto dan Sulistyowati (2012) juga melaporkan bahwa pirolisis plastik PS menghasilkan produk yang mengandung stirena, toluena, isopropil benzene, benzene, dan xylene. Gas yang terbentuk kemudian dikondensasi dan menghasilkan minyak dengan kandungan aromatik dan gas yang mengandung $\mathrm{CO}, \mathrm{CO}_{2}$, dan $\mathrm{CH}_{4}$ (Bajus dan Hejakova, 2010).

Minyak hasil kondensasi pirolisis tergolong ke dalam jenis parafin, isoparafin, olefin, naphthene dan aromatik yang merupakan bahan-bahan penyusun bahan bakar pada umumnya (Obeid dkk., 2014). Oleh karena itu, minyak hasil pirolisis memiliki kualitas yang mirip dengan bahan bakar cair seperti bensin dan solar. Hal ini menyebabkan minyak hasil pirolisis dapat dimanfaatkan sebagai bahan bakar maupun bahan substitusinya. Harshal dan Syailendra (2013) melaporkan bahwa nilai kalor minyak pirolisis dengan solar hampir setara yang nilainya masing-masing adalah 41,8 MJ/kg dan 42,0 MJ/kg. Tamilkolundu dan Murgunsen (2012) juga menjelaskan bahwa minyak hasil pirolisis sampah plastik dapat menjadi alternatif bahan bakar dengan nilai kalori yang mencapai 40,0 MJ/kg. Pernyataan 
ini juga didukung oleh hasil dari beberapa penelitian yang disajikan pada Tabel 2 .

Berdasarkan Tabel 2, terdapat beberapa faktor yang mempengaruhi kualitas dan kuantitas minyak yang dihasilkan. Faktorfaktor tersebut meliputi suhu, waktu, jenis plastik, dan penggunaan katalis dan jenisnya katalisnya (Bajus dan Hajekova, 2010; Santoso, 2010; Tamilkolundo dan Murugesan, 2012; Sarker, 2012; Surono, 2013; Obeid dkk., 2014: Syamsiro dkk., 2014).

a. Suhu dan Waktu

Semakin tinggi suhu dan semakin lama proses pirolisisnya maka akan semakin banyak jumlah minyak yang dihasilkan (Sumarni dan Purwanti, 2008). Dilihat dari produk yang dihasilkan, pirolisis juga menghasilkan gas tetapi diminimalkan dengan peningkatan suhu sehingga minyak yang terbentuk lebih banyak. Seperti hasil penelitian Santoso yang menunjukkan hubungan antara jumlah minyak dan gas yang dihasilkan berbanding terbalik karena adanya peningkatan suhu reaktor. Lebih lanjut Bajus dan Hajekova (2010) melaporkan bahwa nilai kalori dari gas yang terbentuk mencapai 50,8-52,7 MJ/kg yang hampir setara dengan nilai kalori gas metan yaitu 55,7 MJ/kg.

b. Jenis Plastik

Jenis plastik yang digunakan dalam konversi sampah plastik menjadi minyak menentukan kualitasnya. Hal ini dikarenakan monomer penyusunnya yang berbeda yang dapat dilihat pada Tabel 1 dan Tabel 2.

c. Penggunaan Berbagai Jenis Katalis

Sarker dkk. (2012); Sonowane, Shindikar, dan Khaladkar (2014); dan Syamsiro dkk. (2014) menyatakan bahwa penggunaan katalis dalam proses pirolis mampu mempercepat konversi yang menghasilkan minyak dengan kualitas lebih baik. Syamsiro dkk. (2014) menjelaskan bahwa katalis mampu meningkatkan perekahan yang terjadi dalam proses pirolisis. Rantai hidrokarbon yang panjang mampu dikonversi menjadi gas hidrokarbon lebih cepat sehingga minyak yang terbentuk dari kondensasi akan semakin banyak. Penulis yang sama membandingkan kinerja katalis menggunakan zeolit alami dengan zeolit Y. Hasil penelitiannya menunjukkan bahwa zeolit Y mampu mengkonversi rantai hidrokarbon menjadi lebih pendek dibandingkan zeolit alami. Hal ini disebabkan oleh luas permukaan zeolit $\mathrm{Y}$ lebih besar dibandingkan zeolit alami sehingga kontaknya lebih baik. Hasil penelitian yang lain dapat dilihat pada Tabel 2.

Menurut Syamsiro dkk. (2014) dan Obeid dkk. (2014), katalis yang digunakan dalam proses pirolisis dapat dipisahkan dan digunakan kembali sehingga dapat mengurangi biaya operasional. Selain itu, emisi gas yang dihasilkan oleh pirolisis dengan katalis bebas dari dioksin dan furan yang bersifat toksik, sehingga ramah terhadap lingkungan (Harshal dan Syailendra, 2013).

\section{PENGUJIAN MINYAK HASIL PIROLISIS SEBAGAI BAHAN BAKAR}

Santoso (2012) melakukan uji terhadap minyak pirolisis yang dihasilkan melalui kompor. Hasil pengujian menyatakan bahwa efisiensi minyak pirolisis paling tinggi adalah $50 \%$. Santoso (2010) juga membandingkan efisiensi tersebut dengan minyak tanah dan bensin yang nilainya masing-masing adalah $24 \%$ dan $68 \%$. Pengujian minyak hasil pirolisis juga dilakukan sebagai bahan substitusi solar yang digunakan pada kendaraan bermotor berbahan diesel oleh Tamilkolundu dan Murugesan (2012). Konsumsi bahan bakar antara minyak pirolisis yang dicampur dengan solar dibandingkan dengan solar dengan nilai masing-masing adalah 0,61 kg/jam dan 0,69 kg/jam. Sedangkan efisiensi termal yang dicapai oleh campuran minyak adalah $27,4 \%$ dan solar adalah 22,5\%. Bahkan Harshal dan Syailendra (2013) dalam tulisannya menjelaskan bahwa mesin diesel dapat bekerja menggunakan minyak pirolisis sebagai bahan bakar tunggal. Hal ini dikarenakan efisiensi termalnya yang 

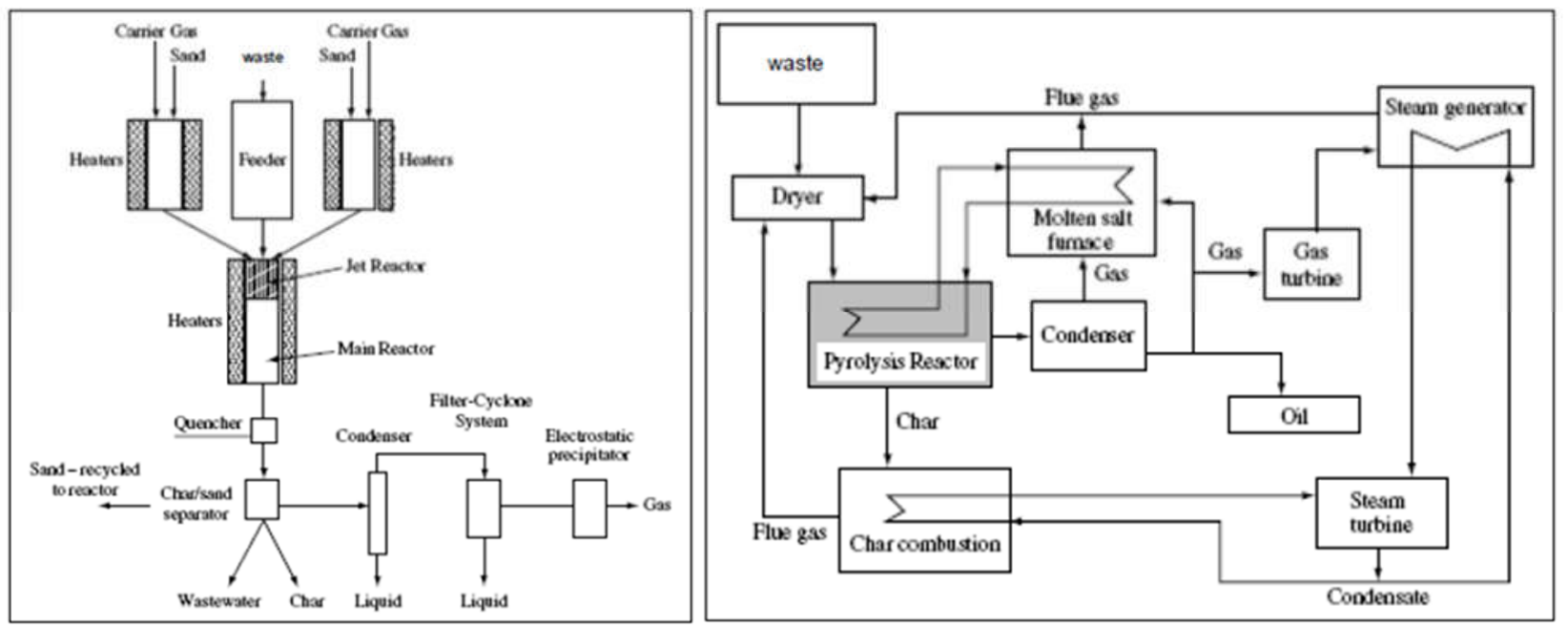

Gambar 2. Bagan Alir Proses Pirolisis Sampah Plastik Menjadi Minyak dan Gas (Sumber: Anonim, 2011)

Tabel 2. Pirolisis Berbagai Jenis Sampah Plastik

\begin{tabular}{|c|c|c|c|c|c|c|}
\hline Penulis & $\begin{array}{c}\text { Jenis } \\
\text { Plastik }\end{array}$ & Suhu $\left({ }^{\circ} \mathrm{C}\right)$ & Waktu & Katalis & Karakteristik Minyak & $\begin{array}{c}\text { Jumlah minyak } \\
(\%)\end{array}$ \\
\hline Sari (2015) & $\begin{array}{l}\text { HDPE, } \\
\text { LDPE, PP, } \\
\text { dan PS }\end{array}$ & - & - & $\begin{array}{l}\text { Tanpa } \\
\text { katalis }\end{array}$ & $\begin{array}{l}\text { Nilai kalor } 42,32 \mathrm{MJ} / \mathrm{kg} \\
\text { yang setara dengan solar } \\
\text { (nilai kalor } 43,0 \mathrm{MJ} / \mathrm{kg} \text { ). }\end{array}$ & - \\
\hline $\begin{array}{l}\text { Obeid dkk. } \\
(2014)\end{array}$ & HDPE & 450 & $\begin{array}{l}45 \\
\text { menit }\end{array}$ & $\mathrm{NaOH}$ & $\begin{array}{c}\text { Minyak yang dihasilkan } \\
\text { mengandung paraffin } \\
\text { sebanyak } 58 \%\end{array}$ & 81 \\
\hline \multirow{2}{*}{$\begin{array}{l}\text { Sonawane dkk } \\
(2014)\end{array}$} & \multirow{2}{*}{$\begin{array}{l}\text { HDPE } \\
\text { HDPE }\end{array}$} & \multirow{2}{*}{550} & $\begin{array}{l}210 \\
\text { menit }\end{array}$ & $\begin{array}{l}\text { Tampa } \\
\text { katalis }\end{array}$ & $\begin{array}{l}\text { Fraksinya hampir setara } \\
\text { dengan bensin, kerosin, } \\
\text { dan diesel (Cs-C20) } \\
\text { dengan nilai kalori } \\
30,15-30,56 \mathrm{MJ} / \mathrm{kg}\end{array}$ & $60-62$ \\
\hline & & & $\begin{array}{l}150 \\
\text { menit }\end{array}$ & Alumina & $\begin{array}{l}\text { Fraksinya hampirsetara } \\
\text { dengan bensin, kerosin, } \\
\text { dan diesel }\left(\mathrm{C}_{5}-\mathrm{C}_{20}\right) \\
\text { dengan nilai kalori } \\
35,17-36,43 \mathrm{MJ} / \mathrm{kg}\end{array}$ & $70-71$ \\
\hline $\begin{array}{l}\text { Tubnonghee } \\
(2010) \text { dalam } \\
\text { Surono }(2013)\end{array}$ & $P E$ dan PP & - & - & $\begin{array}{l}\text { Tanpa } \\
\text { katalis }\end{array}$ & $\begin{array}{l}\text { Fraksi minyak pirolisis } \\
\text { setara dengan solar yang } \\
\text { rantai karbonnya } \mathrm{C}_{12}-\mathrm{C}_{17}\end{array}$ & - \\
\hline $\begin{array}{l}\text { Tamilkolundu } \\
\text { dan Murgunsen } \\
(2012)\end{array}$ & $\begin{array}{l}\text { HDPE dan } \\
\text { PP }\end{array}$ & 520 & - & ZSM-5 & $\begin{array}{l}\text { Minyak yang dihasilkan } \\
\text { setara dengan bensin }\end{array}$ & $20-48$ \\
\hline $\begin{array}{l}\text { Sarker dkk. } \\
(2012)\end{array}$ & LDPE & $150-420$ & - & $\begin{array}{l}\text { Tanpa } \\
\text { katalis }\end{array}$ & $\begin{array}{l}\text { Fraksi minyak setara } \\
\text { dengan minyak tanah } \\
\text { dan diesel/solar yang } \\
\text { rantai karbonnya } \mathrm{C}_{3}-\mathrm{C}_{28}\end{array}$ & 30 \\
\hline \multirow[b]{2}{*}{ Santoso (2010) } & $\begin{array}{l}\text { a. LDPE } \\
\text { b. PP }\end{array}$ & 450 & - & $\begin{array}{l}\text { Tanpa } \\
\text { katalis }\end{array}$ & \multirow{2}{*}{$\begin{array}{c}\text { Nilai kalor minyak rata- } \\
\text { rata adalah } 43,33 \mathrm{MJ} / \mathrm{kg} \\
\text { dan massa jenis } \\
\text { adalah } 0,71-0,77 \mathrm{~kg} / \mathrm{L} \text {. } \\
\text { kedua nilai tersebut } \\
\text { hampir setara dengan } \\
\text { nilai kalor dan massa } \\
\text { jenis minyak tanah dan } \\
\text { bensin }\end{array}$} & $\begin{array}{l}\text { a. } 66 \\
\text { b. } 66\end{array}$ \\
\hline & $\begin{array}{l}\text { a. LDPE } \\
\text { b. PP }\end{array}$ & 300 & - & $\begin{array}{l}\text { Tanpa } \\
\text { katalis }\end{array}$ & & $\begin{array}{l}\text { a. } 34 \\
\text { b. } 9 \text { (karena ikatan } \\
\text { Kristal PP } \\
\text { teratur sehngga } \\
\text { lebih sulit } \\
\text { terdekomposisi) }\end{array}$ \\
\hline
\end{tabular}

mencapai $75 \%$. Berbagai pengujian yang telah diuraikan menunjukkan bahwa minyak hasil pirolisis layak untuk digunakan sebagai bahan bakar tunggal maupun substitusi bahan bakar 


\section{KESIMPULAN}

Pirolisis merupakan teknik daur ulang yang dapat mengubah sampah menjadi bernilai ekonomi yang dapat diaplikasikan. Pirolisis mampu menghasilkan minyak hingga $81 \%$, gas, dan arang. Minyak yang dihasilkan mengandung parafin, isoparafin, olefin, naphthene dan aromatik sehingga dapat dimanfaatkan sebagai bahan bakar. Oleh karena itu, minyak hasil pirolisis layak digunakan sebagai bahan bakar tunggal maupun bahan substitusinya.

Terdapat beberapa faktor yang mempengaruhi proses pirolisis yaitu jenis plastik, suhu dan waktu, penggunaan katalis serta jenis katalisnya. Untuk menghasilkan bahan bakar cair dengan kualitas baik dan kuantitas yang besar disarankan menggunakan katalis. Penggunaan katalis mampu mempercepat proses pirolisis tanpa menambah waktu dan suhu sehingga lebih ekonomis.

\section{DAFTAR PUSTAKA}

Anonim. (2011). Daur Ulang Sampah: Pirolisis dan Gasifikasi. Diakses tanggal $20 \quad$ September 2017. http://www.hmtl.itb.ac.id/

Badan Pusat Statistik, (BPS). (2015). Proyeksi Penduduk Berdasarkan Hasil Sensus Penduduk 2010. Diakses 20 September 2017. http://www.bps.go.id.

Bajus, M. dan Hajekova, E. (2010). Thermal Cracking of The Model Seven Components Mixed Plastiks into Oils/Waxes. Petroleum and Coal.

Guan, Y., Luo, S., Liu, S., Xiao, B., dan Cai, L. (2009). Steam Catalytic Gasification of Municipal Solid Waste for Producing Tar-Free Fuel Gas. International Journal of Hydrogen Energy.

Harshal, P.R., dan Syailendra, L.M. (2013). Waste Plastik Pyrolysis Oil Alternative Fuel for CI Engine. Research Journal of Engineering Sciences.

Liu, S., Zhou, Y., Yi, C. (2012). Syngas Production by Catalytic Steam Gasification of Municipal Solid Waste in Fixed-Bed Reactor. Energy.

Marnoto, T., dan Sulistyowati, E. (2012). Tinjauan Kinetika Pyrolisis Limbah Polystiren. Dalam Prosiding Seminar Nasional Teknik Kimia "Kejuangan". Yogyakarta.
Mujiarto, I. (2005). Sifat dan Karakteristik Material Plastik dan Bahan Aditif. Traksi.

Nishino, J., Itoh, M., Ishinomori, T., Kubota, N., dan Uemichi, Y. (2003). Development of a Catalytic Cracking Process for Converting Waste Plastiks to Petrochemicals. Journal of Material Cycles and Waste Management.

Obeid, F., Zeaiter, J., Al-Muhtaseb, A.H., dan Bouhadir, K. (2014). Thermo-Catalytic Pyrolysis of Waste Polyethylene Bottles in A Packed Bed Reactor with Different Bed Materials and Catalysts. Energy Conversion and Management.

Rodiansono, Trisurnayanti, W., dan Triyono. (2006). Hidrorengkah Polipropilena Menjadi Fraksi Bensin Menggunakan Katalis Zeolit Alam Aktif (Z), $\mathrm{Ni} / \mathrm{Z}, \mathrm{Ni} / \mathrm{Z}-\gamma-\mathrm{Al}_{2} \mathrm{O}_{3}$. Journal of Alchemy.

Santoso, J. (2010). Uji Sifat Minyak Pirolisis dan Uji Performasi Kompor Berbahan Bakar Minyak Pirolisis dari Sampah Plastik. Diakses tanggal 20 September 2017. http://lppm.uns.ac.id/uji-sifatminyak-pirolisis-dan-uji-performasikompor-berbahan-bakar-minyakpirolisis-dari-sampah-plastikpolyethylene-universitas-sebelasmaret.html

Sari, Y. (2015). Analisis Potensi Pemanfaatan Sampah Plastik sebagai Bahan Bakar Alternatif dalam Upaya Meningkatkan Kualitas Sanitasi Lingkungan: Studi Kasus Tempat Pembuangan Sementara (TPS) Kawasan Perumnas Monang Maning, Denpasar. Skripsi. Universitas Udayana. Bali.

Sonowane, Y.B., Shindikar, M.R., dan Khaladkar, M.Y. (2014). Onsite Conversion of Thermoplastik Waste into Fuel by Catalytic Pyrolysis. International Journal of Innovative Research in Science, Engineering and Technology.

Straka, P., dan Bicakov, O. (2014). Hydrogen-Rich Gas as A Product of TwoStage Co-Gasification of Lignite/Waste Plastiks Mixtures. International Journal of Hydrogen Energy.

Sumarni., dan Purvanti, A. (2008). Kinetika Reaksi Pirolisis Plastik Low Density Polyethilen (LDPE). Jurnal Teknologi, Vol. 1, No. 2: 135 -140 
Surono, U.B. (2013). Berbagai Metode Konversi Sampah Plastik Menjadi Bahan Bakar Minyak. Jurnal Teknik, Vol.3, No. 1.

Syamsiro, M., Saptoadi, H., Norsujianto, T., Noviasri, P., Cheng, S., Alimuddin, Z., dan Yoshikawa, K. (2014). Fuel Oil Production from Municipal Plastik Wastes in Sequential Pyrolisis and Catalytic Reforming Reactors. Conference and Exhibition Indonesia Renewable Energy and Energy Conservation. 